\title{
Acute hypocomplementemic post-infectious glomerulonephritis as a complication of sinus-related orbital cellulitis: case report
}

\author{
Glomerulonefrite pós-infecciosa hipocomplementêmica aguda como complicação \\ de celulite orbitária relacionada aos seios paranasais: relato de caso
}

\author{
Jayter Silva Paula ${ }^{1}$ \\ Antonio Augusto Velasco e Cruz ${ }^{2}$ \\ Patrícia Mitiko Santelo Akaishi ${ }^{3}$ \\ Tiana Burman ${ }^{4}$
}

\section{ABSTRACT}

Group A beta-hemolytic streptococcus is the most common agent implicated in post-infectious acute glomerulonephritis. We report a case of acute poststreptococcal glomerulonephritis associated with sinus-related orbital abscess in an 11-year-old boy treated with surgical drainage and intravenous ceftriaxone and clindamycin. Twelve days after supportive measures, renal function was normalized. We also discuss this potentially severe nonsuppurative complication of orbital cellulitis caused by group A beta-hemolytic streptococcus.

Keywords: Cellulitis/diagnosis; Orbit; Glomerulonephritis; Streptococcal infections; Eye infections, bacterial; Sinusitis/complications; Human; Children; Case reports [Publication type]

\section{INTRODUCTION}

Trabalho realizado no Departamento de Oftalmologia, Otorrinolaringologia e Cirurgia de Cabeça e Pescoço Faculdade de Medicina de Ribeirão Preto - Universidade de São Paulo - Brasil.

Professor Doutor Colaborador do Departamento de Oftalmologia, Otorrinolaringologia e Cirurgia de Cabeça Pescoço da Faculdade de Medicina de Ribeirão Preto da Universidade de São Paulo - USP - Ribeirão Preto (SP) Brasil.

2 Professor Titular do Departamento de Oftalmologia, Otorrinolaringologia e Cirurgia de Cabeça e Pescoço da Faculdade de Medicina de Ribeirão Preto da USP Ribeirão Preto (SP) - Brasil.

${ }^{3}$ Médica Assistente do Departamento de Oftalmologia, Otorrinolaringologia e Cirurgia de Cabeça e Pescoço da Faculdade de Medicina de Ribeirão Preto da USP Ribeirão Preto (SP) - Brasil.

${ }^{4}$ Pós-graduada - doutorado pelo Departamento de Oftalmologia, Otorrinolaringologia e Cirurgia de Cabeça e Pescoço da Faculdade de Medicina de Ribeirão Preto da USP - Ribeirão Preto (SP) - Brasil.

Corresponding author: Jayter Silva Paula. Departamento de Oftalmologia, Otorrinolaringologia e Cirurgia de Cabeça e Pescoço, Hospital das Clínicas de Ribeirão Preto, $12^{\circ}$ andar - Campus USP - Av. Bandeirantes, 3900 - Ribeirão Preto (SP) CEP 14049-900

E-mail: jayterdepaula@yahoo.com.br

Proprietary interest statement: There is no financial interest in this study.

Recebido para publicação em 02.10 .2007

Última versão recebida em 11.02.2008

Aprovação em 20.02.2008

Nota Editorial: Depois de concluída a análise do artigo sob sigilo editorial e com a anuência do Dr. Kimble Matos sobre a divulgação de seu nome como revisor, agradecemos sua participação neste processo.

\section{CASE REPORT}

A previously healthy 11-year-old boy was evaluated for an acute inflammation in the right orbit. On examination, the right eye was proptotic (Hertel measurements were 22 and $12 \mathrm{~mm}$ ) with swelling of the upper and lower eyelids. Ocular motility was limited in all gaze directions. Visual acuity was 20/40 of the right eye (OD) and 20/25 of the left (OS). Intraocular pressure was $40 \mathrm{mmHg}$ in OD and $12 \mathrm{mmHg}$ in OS. Orbital computed tomography (CT) disclosed a right inferomedial orbital abscess and ipsilateral pansinusitis (Figures 1 and 2). A cantholysis was performed on the OD during admission. The next day the boy underwent middle turbinate resection and ethmoidal and maxillary sinus drainage under general anesthesia. The orbit was approached by an inferior fornix transconjunctival incision. Abundant pus was aspirated from the orbit and sinuses. The culture grew positive for Group A $\beta$-hemolytic streptococci. The patient was treated with parenteral antibiotics (ceftriaxone and clindamycin) and five days after surgery he was discharged with full recovery of eye motility and complete resolution of proptosis. Four days after discharge the 


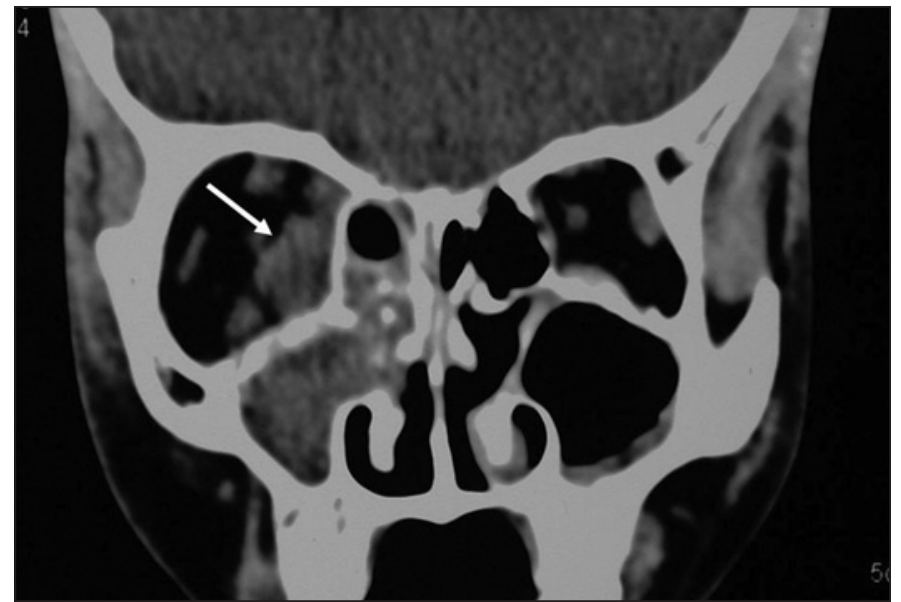

Figure 1 - Coronal CT scan showing a right inferomedial orbital abscess (white arrow) and ipsilateral pansinusitis

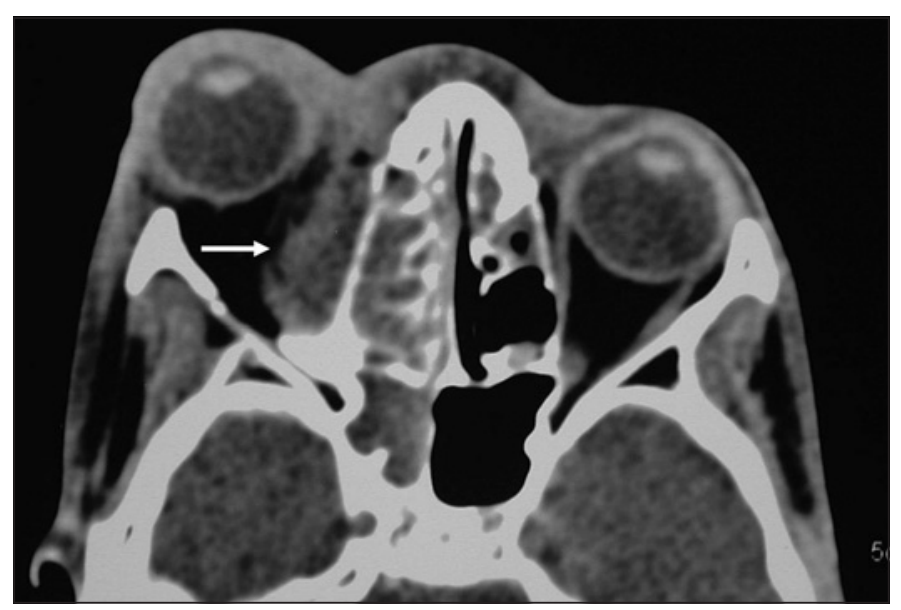

Figure 2 - Axial CT section demonstrates marked anterior displacement of the right eye due to the extraconal inferomedial abscess (white arrow)

child presented with facial edema and signs of distress. A pediatric evaluation disclosed generalized edema and systemic hypertension $(200 \times 100 \mathrm{mmHg})$, with no other cardiac findings. Blood count, antinuclear antibody, rheumatoid factor, LE cells and serologic tests were within normal limits. Urinalysis showed hematuria and mild proteinuria. Seric complement component levels $\mathrm{C} 3$ and $\mathrm{C} 4$ were low. The patient was diagnosed as having acute poststreptococcal glomerulonephritis and was treated with furosemide, nifedipine and salt and fluid restriction. The outcome was favorable and after 12 days of hospitalization the boy was discharged without any signs of renal dysfunction, and with increase of complement levels afterwards.

\section{DISCUSSION}

Postinfectious acute glomerulonephritis may be induced by several bacteria including $S$. aureus, $S$. epidermidis, meningococcus, atypical mycobacterium, and Corynebacterium ${ }^{(2)}$. Ho- wever, group A $\beta$-hemolytic streptococcus is the most common causative agent implicated, mainly after acute pharyngitis. AGN is not a common complication, with a frequency less than $5 \%$ after a streptococcal infection ${ }^{(2,4)}$. These associations are usually sporadic, notwithstanding they may present in epidemic events in some countries. A progressive renal disease is quite rare and a complete recovery with normal diuresis occurs in more than $90 \%$ of treated cases ${ }^{(4)}$.

The pathogenesis of the disease is linked to the production of specific bacterial antigens which are targeted by the host immune response. Immune complexes are then formed and deposited within the glomeruli, activating the complement cascade and attracting inflammatory cells. The resulting inflammatory reaction provokes proliferation of mesangial and endothelial cells and produces bloodless glomeruli, a decrease in renal filtration and retention of fluid and salt(2-3).

The association between sinus-related orbital cellulitis and AGN seems to be quite rare. In a literature search using the Medline database we could not find any report on this association. AGN is usually controlled with supportive measures. However, when the disease is not recognized, serious effects such as congestive heart failure may ensue. The present report highlights the necessity of clinical evaluation of any children with sinus-related orbital cellulitis. Ophthalmologists should be aware that orbital infections can induce renal complications.

\section{RESUMO}

Os estreptococos beta-hemolíticos do grupo A são os agentes mais comumente envolvidos na glomerulonefrite aguda pós-infecciosa. Relatamos um caso de glomerulonefrite pós-estreptocócica aguda associada a um abscesso orbitário secundário à sinusite, em menino de 11 anos de idade, o qual foi tratado com ceftriaxona e clindamicina endovenosas e drenagem cirúrgica. Doze dias após tratamento de suporte, a função renal se normalizou. Também discutimos a importância desta grave e potencial complicação não supurativa das celulites orbitárias causadas pelos estreptococos beta-hemolíticos do grupo A.

Descritores: Celulite/diagnóstico; Órbita; Glomerulonefrite; Infecções estreptocócicas; Infecções oculares bacterianas; Sinusite/complicações; Humanos; Crianças; Relatos de casos [Tipo de publicação]

\section{REFERENCES}

1. Connelll B, Kamal Z, McNab AA. Fulminant orbital cellulitis with complete loss of vision. Clin Experiment Ophthalmol. 2001;29(4):260-1.

2. Cole BR, Salinas-Madrigal L. Acute proliferative glomerulonephritis and crescent glomerulonephritis. In: Barratt TM, Avner ED, Harmon WE, editors. Pediatric nephrology. $4^{\text {th }}$ ed. Philadelphia: Lippincott; 1999. p.669-89.

3. Strife CF, McAdams AJ, McEnery PT, Bove KE, West CD. Hypocomplementemic and normocomplementemic acute nephritis in children: a comparison with respect to etiology, clinical manifestations, and glomerular morphology. J Pediatr. 1974;84(1):29-38.

4. Nissenson AR, Baraff LJ, Fine RN, Knutson DW. Poststreptococcal acute glomerulonephritis. fact and controversy. Ann Intern Med. 1979;9(1):76-86. 